\title{
離散要素法によるフェロコークス製造用竪型乾留炉の 炉体大型化に伴う粒子の降下挙動変化の解析
}

\author{
昆 竜矢 ${ }^{1) *} \cdot$ 夏井 $\quad$ 俊悟 ${ }^{2)} \cdot$ 植田 $\quad$ 滋 $^{1)} \cdot$ 井上 $\quad$ 亮 $^{3)} \cdot$ 榎枝 $\quad$ 成治 ${ }^{4)} \cdot$ 有山 達郎 ${ }^{5)}$
}

Analysis of the Burden Descending Behavior in an Enlarged Shaft Furnace for Ferro-Coke Production by DEM

Tatsuya Kon, Shungo Natsui, Shigeru Ueda, Ryo Inoue, Seiji Enoeda and Tatsuro Ariyama

Synopsis : With the aim to decrease the reducing agent rate in blast furnace, the use of ferro coke containing metallic iron as a catalyst was proposed. This new burden material is expected to lower thermal reserve zone temperature. For the production of ferro coke, the use of a vertical coke oven is examined to realize the optimum carbonizing process. In this type of the oven, the burden materials have a distribution in residence time due to the friction effect on the wall and the interaction between the burdens. It has a great influence on the properties and quality of the ferro coke. Increasing the size of the vertical coke oven is essential for producing a large amount of ferro coke efficiency with stable quality. In this study, the burden descending behavior in an enlarged vertical coke oven was calculated by Discrete Element Method (DEM). The effects of the shape of the discharging part and the discharging method on the residence time of the burden were analyzed based on the calculated results. In addition, considering the reinforcement of the enlarged coke oven, the burden descending behavior in the vertical coke oven with reinforcing horizontal beam inside was also examined.

The calculation results showed that distribution variation in the residence time could be decreased by increase in the size of the vertical coke oven. Furthermore, the results showed the possibility of controlling the residence time by controlling the discharge method.

Key words : ironmaking; ferro coke; $\mathrm{CO}_{2}$ reduction; vertical type of coke oven; moving bed; discrete element method; residence time distribution.

\section{1. 緒言}

高炉で用いる炭材の反応性の向上は, 熱保存帯の温度を 低下させ高炉での炭材の利用効率を向上させると考えられ ている。このため高反応性コークスの製造および利用技術 に関する研究開発が行われている ${ }^{1-4)}$ 。この中で, 微粉の石 炭とペレットフィードから構成され, 触媒作用のある鉄分 を多量に含むフェロコークス ${ }^{3)}$ は高反応性炭材として, 基 礎検討結果並びに工業プロセス化に向けた研究が報告され ている4)。フェロコークスの製造工程では, 従来の室炉式 コークスと異なり，ブリケット等に塊成化した原料を乾留 するため，竪型乾留炉の利用により炉頂より装入した塊を 炉内で加熱し, 炉下部で回収する連続式プロセスが従来プ ロセスに比べ効率的であると考えられる。

具体的な乾留方法を検討するために, 前報 ${ }^{5)}$ ではフェロ コークス製造用の竪型乾留炉における粒子降下特性を, 冷 間実験による観察, また個別粒子の運動解析が可能な離散 要素法 (以下, DEM : Discrete Element Method) ${ }^{6}$ を用いて
定量的に検討した。前報では，フェロコークス製造に用い る竪型乾留炉内の固体流動, 滞留時間分布などを解析し, 適切な炉体設計, 操業指針を得ることを目的とし, 降下に 伴う粒子拡散のモデル化を行った。さらに，そのモデルを 用い, 実機プロセスでの乾留時間の分布について検討した。 この結果, 粒子と壁の摩擦により壁に接した粒子の降下速 度が遅く, 粒子の滞留時間分布が拡大する原因になること が明確に示された。高炉内の装入物降下挙動については, 壁からの一定距離の領域で壁との摩擦によって粒子混合が 生じることが報告されている ${ }^{7,8)}$ 。粒子の滞留時間を一定に 制御するためには壁面の影響を小さくする必要がある。

ここで, 移動する粒子量に対して壁面の効果を相対的に 低下させるためには，炉体の大型化が有効な手段である。 また大型化はフェロコークス実用化のための生産量の確保 に必要な技術である。石炭の乾留には熱の供給が必要であ り, 壁面からの外熱や内部に高温ガスを流通することが考 えられる。炉径の拡大は水平方向の温度分布を増大し，乾 留の制御を困難にする可能性がある。そこで外熱による乾

平成25年9月20日受付 平成26年1月16日受理 (Received on Sep. 20, 2013 ; Accepted on Jan. 16, 2014)

1）東北大学多元物質科学研究所 (Institute of Multidisciplinary Research for Advanced Materials, Tohoku University, Sendai 980-8577)

2) 北海道大学大学院工学院材料科学専攻 (Division of Materials Science and Engineering, Faculty of Engineering, Hokkaido University)

3) 秋田大学 (Akita University)

4) JFEスチール (株) スチール研究所機械研究部 (Steel Research Lab., Mechanical Engineering Research Dept., JFE Steel Corporation)

5) 東北大学名誉教授 (Emeritus professor, Tohoku University)

* Corresponding author : E-mail : b1tm5009@s.tohoku.ac.jp

DOI : http://dx.doi.org/10.2355/tetsutohagane.100.593 
留を効果的に行うために矩形の炉体を用いることが提案で きる。これを用いた場合, 矩形の長辺より熱あるいは高温 ガスを導入することにより温度分布を短辺の範囲に維持す ることが出来る。また, 長辺を延長することにより乾留条 件に影響を与えずにスケールアップを行うことが出来る点 に長所がある。

本研究では, スケールアップを想定した矩形竪型乾留 炉の形状での粒子の炉内降下挙動をDEMを用いて解析を 行った。炉内の粒子は重力により自然に降下するものとし て, 炉底の形状および一度の排出量を変化させ, 炉内粒子 の縦方向の分散の変化を算出した。また, 実炉体のスケール アップ時の強度保持を考慮し, 炉内に円柱状の補強材を水 平に設置した場合の，支柱の粒子運動への影響も考察した。

\section{DEMによる炉内固体流れのシミュレーション}

\section{$2 \cdot 1$ DEMの基礎方程式}

DEM は対象とする全ての粒子の動きを接触力により決 定する数值計算である。粒子に働く外力として, 重力と, その粒子に直接触れる他の粒子，および壁の影響を考慮し た。ある粒子に働く外力がわかれば，二ュートンの運動の 第 2 法則に基づく運動方程式を解くことで，加速度が求め られる。これを時間積分することにより粒子の変位が求ま り，その運動軌跡を表現することが可能となる。

DEMについては既報 ${ }^{5)} て ゙$ 述べたためここでは概略の説 明にとどめる。粒子間の応力にはVoigt モデルを用いた。こ のモデルでは接触点の法線, せん断方向にはそれぞれ2粒 子の相対変位によって弾性変形し反力を発生するバネと相 対速度に比例した抗力を発生する粘性ダッシュポットが 並列に配置される。また, 摩擦力による相互作用を考慮し, せん断方向には摩擦スライダーを導入した。このとき, 2 粒子間に働く力による接触粒子の並進の変位 $u_{i}$ は次式で表 される。

$$
m_{i} \frac{d^{2} u_{i}}{d t^{2}}+\eta \frac{d u_{i}}{d t}+K u_{i}=0
$$

また，回転変位 $\omega_{i}$ は次式で表される。

$$
I_{i} \frac{d^{2} \omega_{i}}{d t^{2}}+\eta \frac{d \omega_{i}}{d t}+K R_{i}^{2} \omega_{i}=0
$$

$m, R, I$ および $\omega$ はそれぞれ粒子質量，半径，慣性モーメン 卜，回転角速度を表す。また， $K, \eta$ はばね定数とダッシュ ポットの粘性係数である。一般の粉体では，1個の粒子の 周りに多数の粒子が接触しているので, それら全ての接触 点に対して (1) 式，(2) 式が成立する。

ある時刻 $T$ における法線方向 $n$ の接触力 $F_{n}$ およびせん断 方向 $s$ の接触力 $F_{s}$ は，ばねによる弾性力 $e$ とダッシュポッ 卜による粘性抵抗力 $d$ の和として，それぞれ (3) 式，(4) 式
で表される。

$$
\begin{aligned}
& F_{n, T}=\sum_{j}\left(e_{n, T}+d_{n, T}\right) \\
& F_{s, T}=\sum_{j}\left(e_{s, T}+d_{s, T}\right) .
\end{aligned}
$$

(3) 式中の $e_{n, T}, d_{n, T}$ は (5) 式で表される。

$$
e_{n, T}=e_{n, T+\Delta T}+K_{n} \Delta u_{n}, d_{n, T}=\eta_{n} \frac{\Delta u_{n}}{\Delta t}
$$

ばね定数と粘性抵抗力は（6）式である。

$$
K_{n}=2 D_{b}\left(\frac{1-v_{i}^{2}}{E_{i}}+\frac{1-v_{j}^{2}}{E_{j}}\right)^{-1}, \eta_{n}=2 \sqrt{m K_{n}}
$$

ここで $E$ と 半径を示す。また，(4) 式中の $e_{s, T}, d_{s, T}$ は（7）（8）式で表さ れる。

$$
\begin{aligned}
& e_{s, T}=e_{s, T+\Delta T}+K_{s} \Delta u_{s}, d_{s, T}=\eta_{s} \frac{\Delta u_{s}}{\Delta t} \ldots \ldots \ldots \ldots \ldots \ldots \ldots \ldots \ldots \ldots \ldots \ldots \\
& K_{s}=8 D_{b}\left\{\frac{2\left(2-v_{i}\right)\left(1+v_{i}\right)}{E_{i}}+\frac{2\left(2-v_{j}\right)\left(1+v_{j}\right)}{E_{j}}\right\}, \eta_{s}=2 \sqrt{m K_{s}}
\end{aligned}
$$

$\Delta T$ はタイムステップである。粒子間せん断方向について, クーロンの摩擦法則から得られるせん断力より大きな力は 作用しない。せん断応力が粒子間摩擦力より大きい場合は すべりが生じるため, 摩擦係数を $\mu$ として (9) 式が成り立つ。

$$
F_{s}=\mu\left|F_{n, i j}\right|
$$

DEMにおいて個々の粒子は完全な真球として取り扱われ る。しかし, 実際の粉体は不定形状であり, 真球に比べて 回転しにくい。このような粒子形状を表現する為に, 回転 方向のトルク $T$ と逆向きの回転抵抗 $M$ を導入した。

$$
\begin{aligned}
& I_{i} \frac{d \omega_{i}}{d t}=\sum_{j}\left(T_{i j}+M_{r}\right) \\
& M_{r}=\frac{3}{8} \alpha \cdot D_{b}\left|F_{n}\right| \ldots \ldots
\end{aligned}
$$

$T_{i, j}$ は粒子 $i$ が受けるトルク,$M_{r}$ は接触面でのせん断応力を 示す。 $\alpha$ は回転抵抗係数であり，粒子表面物性に基づいて 決定した ${ }^{9)}$ 。

\section{$2 \cdot 2$ DEMの計算条件}

パイロットプラントスケールの竪型乾留炉をスケール アップすることを想定して DEMにより堅型炉の解析モデ ルを作成した。Fig.1に示す (a) のように上部の幅 $1 \mathrm{~m}$ 奥行 $1 \mathrm{~m}$ の正四角柱と下部四面が斜面して狭くなるテーパー部 により構成される高さ $16 \mathrm{~m}$ をつのユニットとし，これ を並列に並べ大型の竪型乾留炉を構成した。各ユニット間 
には壁面は存在しない。(b) は本計算の対象とした五連ユ ニットの形状を示す。下部は個々のユニットが独立した テーパー部を有する形状 (c) と, 五連のユニット全体が一 つのテーパー部を有する形状 (d) を想定し, 炉下部形状が 与える影響について解析を行った。また，炉体補強用の支 柱を用いることを想定し，二番目と四番目のユニットの中 央, 下から $8.0 \mathrm{~m}$ の位置にユニットの列と直交するように 支柱を設置した計算も行った。支柱は円柱形で任意に径を 設定した。

粒子の移動による降下の表現のために, 炉底部に粒子が 消失する領域を設定し，その領域に存在する粒子を一定時 間間隔で消去することで粒子の排出を表現した。炉底から 上方に $15 \mathrm{~m}$ の位置にストックラインを設け, 充填層の高さ がこのストックラインを超えるように逐次粒子を上部より 落下し, 供給を行った。移動層の降下は, 炉底部での消失 領域の体積と粒子消去間隔を変化させることで調整した。 粒子径は，フェロコークスの実粒子径を想定して $6.0 \mathrm{~cm}$ と した。粒子の密度は, フェロコークスの值 ${ }^{5)}$ を用いた。フェ ロコークスは乾留前後によってその物性が異なるが, 乾留

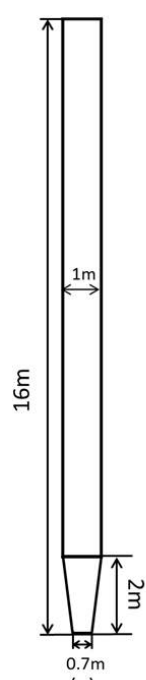

(a)

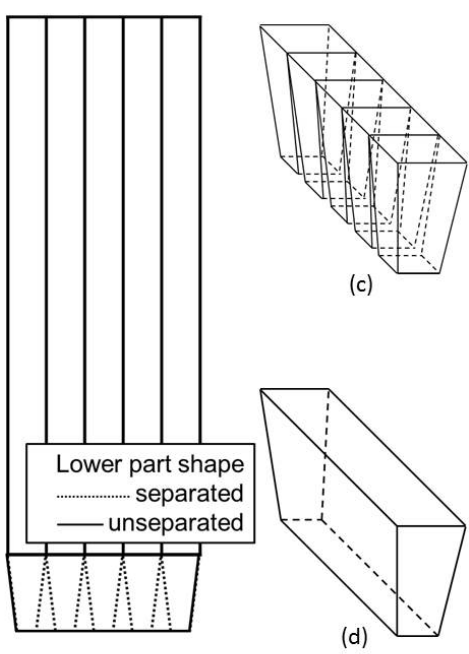

(b)
Fig. 1. Schematic diagram of furnace calculated in present study.

Table 1. Calculation conditions.

\begin{tabular}{lc}
\hline Particle radius [cm] & 3.00 \\
\hline Particle Young modulus [GPa] & 0.54 \\
\hline Particle Poisson's ratio [-] & 0.22 \\
\hline Particle density [g/cm $\left.{ }^{3}\right]$ & 1.05 \\
\hline Friction coefficient (particle-particle) [-] & 0.25 \\
\hline Particle rolling friction coefficient [-] & 0.30 \\
\hline Friction coefficient (particle-wall) [-] & 0.45 \\
\hline Time step [s] & $1.00 \times 10^{-4}$ \\
\hline Particle number [-] & $80000(1 \mathrm{unit})$ \\
\hline
\end{tabular}

前後の測定値の平均值を用いた。粒子間打よび粒子一壁間 の接触摩擦係数はフェロコークス粒子, また耐火物壁を用 いたせん断試験により実測して求めた值 ${ }^{5)}$ を用いた。計算 に用いた計算条件を, Table 1 に示す。

フェロコークス製造プラントでの原料の滞留時間は数 時間に及ぶため, 実際の時間スケールで計算を行うことは 極めて困難である。本研究では, シミュレーションでの排 出時間間隔の短縮により計算時間の短縮を行った。計算結 果を用いて, 帯留時間の換算を行い実炉での滞留時間分布 を求めた。シミュレーションでの降下挙動と実炉での降下 挙動との関係を Fig.2 に示す。一定の時間間隔で粒子の排 出を行うため, 降下挙動は図中 step $1 \sim 3$ の様に排出, 降下, 停止に分けられる。シミュレーション (a) では計算時間短 縮のため, 排出間隔を小さくしている。実際の降下挙動 (b) ではstep1,2に対して, step3にかかる時間が極めて長いた め, step3にかかる時間と排出間隔はほほ等しくなる。この とき,一回の排出で原料が降下する距離は排出量によって 決まる。このため, 同一の排出量の場合, 原料がある距離 を降下するのに必要な排出回数は, シミュレーションと実 炉で同じ回数となる。シミュレーションで求めた排出回数 と任意に設定した排出時間間隔から, 実炉での滞留時間分 布を求めることができる。

\section{3. 炉内充填層降下挙動の解析結果}

\section{$3 \cdot 1$ 炉下部形状の影響}

粒子の降下挙動が把握しやすいように, 炉底から $3 \mathrm{~m}, 6$ $\mathrm{m}, 9 \mathrm{~m}, 12 \mathrm{~m}$ の位置に他の粒子と物性が同一であるトレー サー粒子を設定した (Fig. 3)。排出部の下部 $0.5 \mathrm{~m}$ に存在す る粒子を 1.0 秒ごとに消去し, 充填層の降下を制御すると

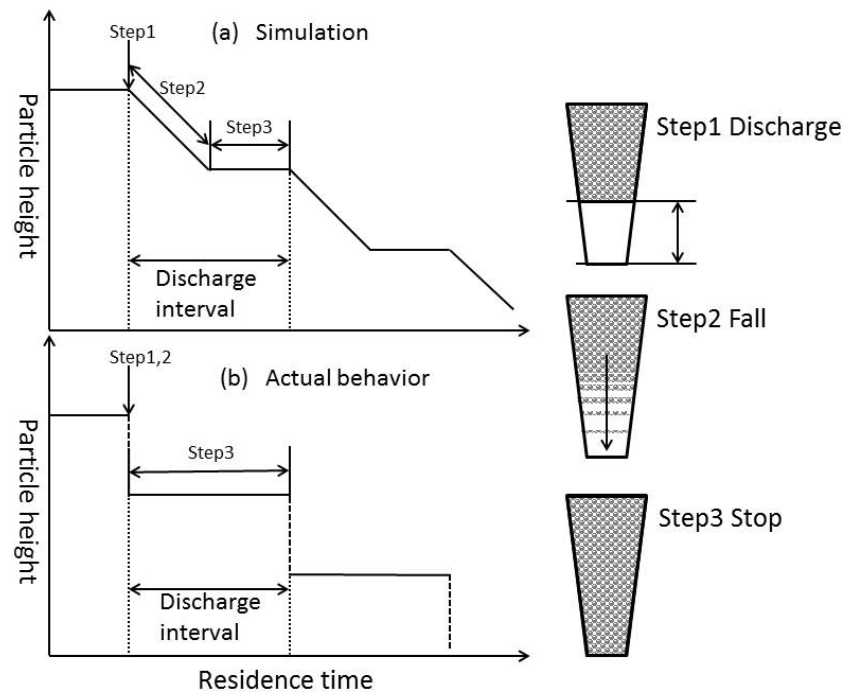

Fig. 2. Comparison between residence times of particle discharging in simulation and actual behavior. 


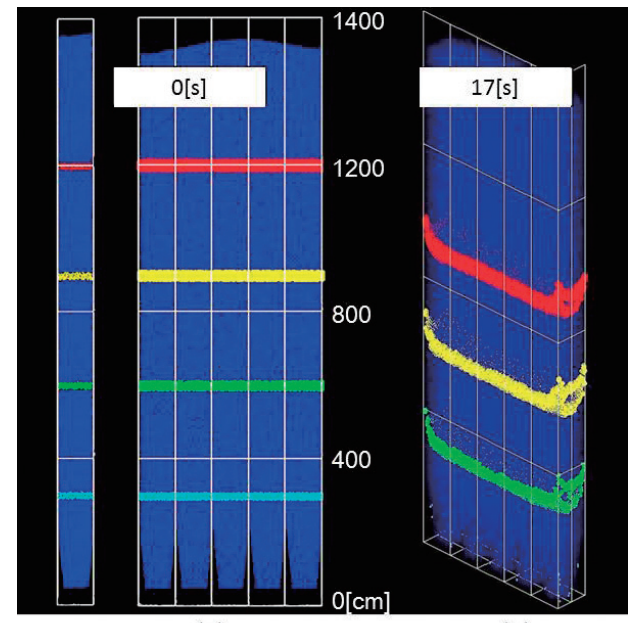

(a)

(b)

Fig. 3. Positions of tracer at $0 \mathrm{~s}$ and $17 \mathrm{~s}$.
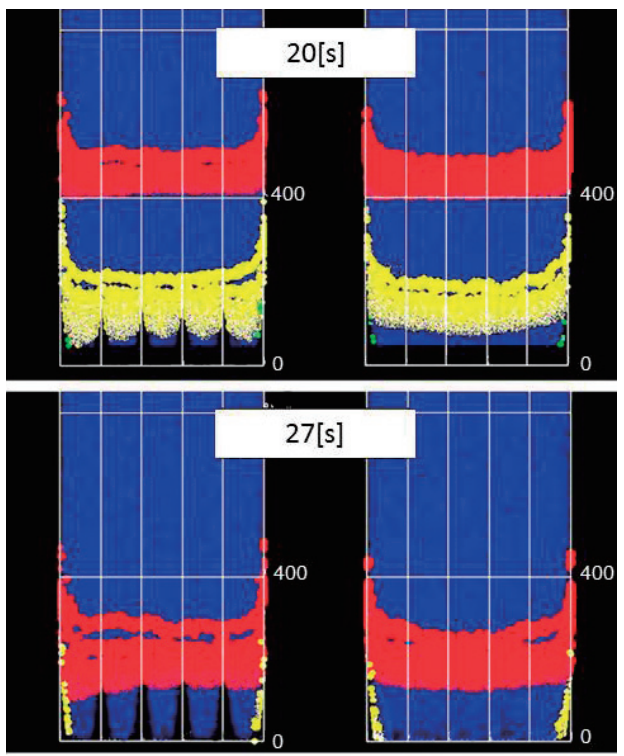

(a)

(b)

Fig. 4. Tracer particle distribution at $20 \mathrm{~s}$ and $27 \mathrm{~s}$.

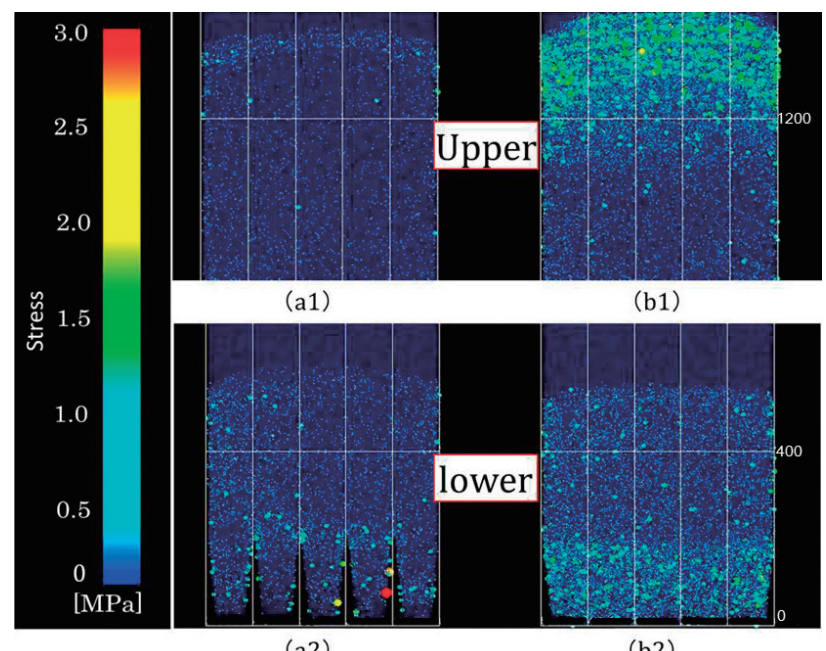

(a2)

(b2)

Fig. 6. Influence of discharge area shapes on stress distribution.

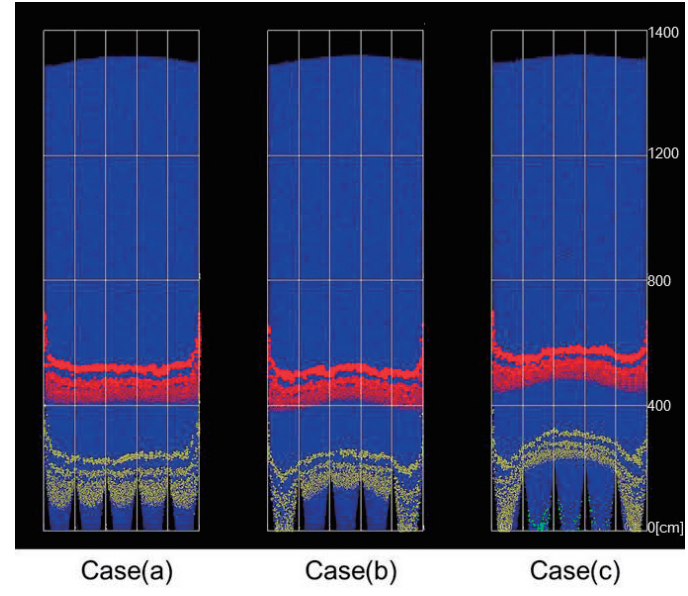

Fig. 10. Tracer particle distributions for discharging conditions (a), (b), and (c).

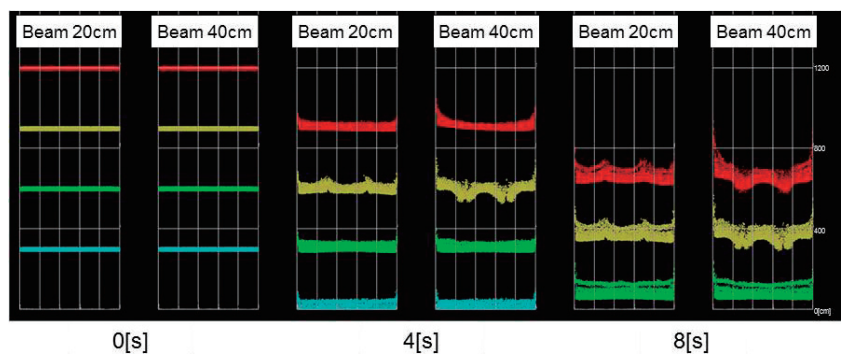

Fig. 12. Tracer particle distribution at $0 \mathrm{~s}, 4 \mathrm{~s}$ and $8 \mathrm{~s}$ with beam.

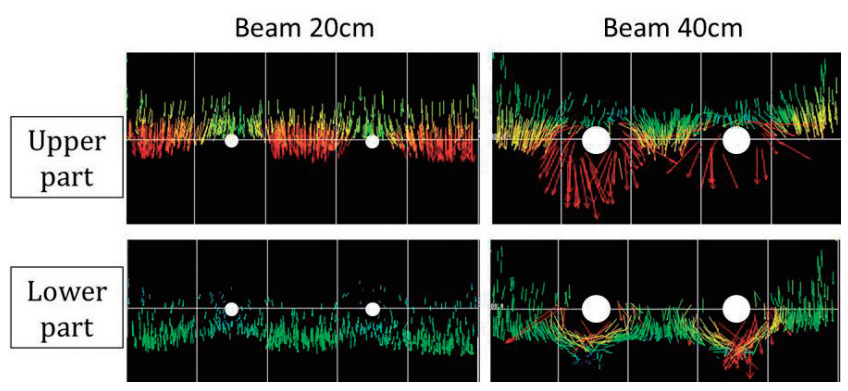

Fig. 13. Influence of diameter of beam on particle velocity at vicinity of beam.

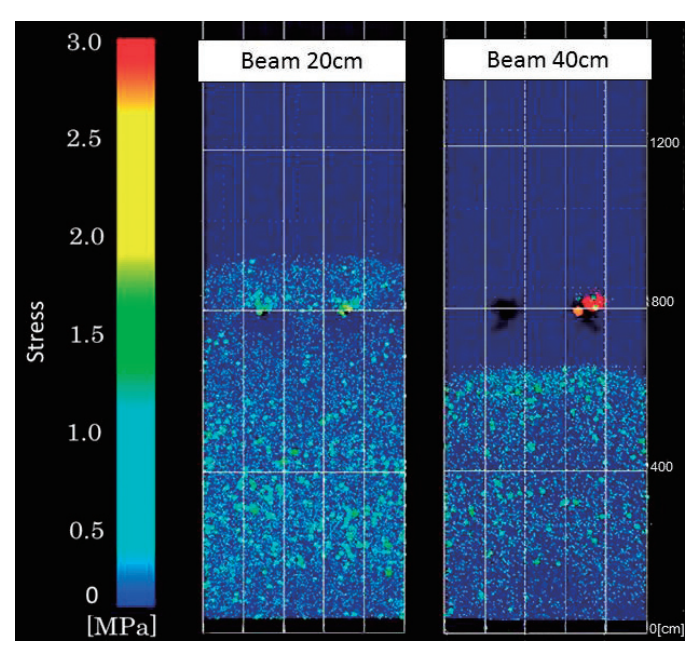

Fig. 14. Influence of beam diameter on stress distribution. 
17秒後にFig.3（b）のように壁面近傍の粒子の降下が遅れ， 中心部の粒子が先行する。Fig.4に20秒後と 27 秒後のト レーサーの分布を示す。壁面近くの粒子の降下が遅いこと が判る。眓の左右の壁付近の粒子は眓の手前および奥の壁 の影響を受けるため, 特に降下が遅れることが判る。この 二面の壁付近の粒子の遅れは前報の結果とほぼ一致する。 左右の壁は図の左右方向に1ユニット程度の範囲で粒子の 降下に影響を与えるため, 中央の 3 ユニット内の粒子は手 前と奥の壁の影響は明確に受けているが，左右の壁の影響 をほとんど受けない。この壁面影響の減衰はFig.5 に示す ように実験でも確認できる。この実験は実炉の $1 / 20$ スケー ルの容器に $\phi 2 \mathrm{~mm} \times 3 \mathrm{~mm}$ の円筒形プラスチックペレッ 卜を充填し，炉下部より往復プラウを用い排出した際の， 降下挙動の観察を行ったものである。初期条件 (a) では炉 頂部に位置する白色のペレットが，乾留が終了する位置ま で到達した際 (b) には, 左右の炉壁面でのみペレットの遅 れが確認でき，炉中心部ではほぼ均一に降下している。こ のことから炉のサイズの拡大は降下挙動の均一化に有効で あることが確認できる。

次に 27 秒後の下部のテーパー部を各ユニット毎に設置 した場合 (a)と，全体が一体化したテーパー部を設置した 場合 (b) での比較を行う。テーパー部壁からの粒子に加わ る応力の影響で，(a) では中央のユニットの粒子の降下が 遅く，(b)では中央が速い降下を示した。これは，下部の テーパーによる縮流と摩擦が (a) ではより大きく影響し, 粒子の降下が妨げられ，粒子の降下速度に差が生じたため であると考えられる。

応力分布を Fig.6に示す。(a1, b1) と（a2, b2) はそれぞれ 炉内上部と下部 (位置)において, 粒子が降下し応力付加 が起きた時の応力分布を示している。粒子には排出時の降 下に合わせて上方に応力が伝搬するようにかかることが分 かった。カラースケールはある1つの粒子に作用する粒子 間応力 $\sigma$ を以下の式から導出した值を示す。

$$
\sigma_{n, T}=\frac{\sum_{j}\left(e_{n, T}+d_{n, T}\right)}{4 \pi R^{2}}
$$

ここでRは対象粒子の半径を示す。下部に個別のテーパー 部を設置した（a）では局所的にテーパー部から粒子に応力 がかかるため，炉下部の粒子のほとんどは応力の低い值を 示す。一方，(b) では手前と奥の傾斜した壁から粒子全体 に応力がかかるが, 全体の粒子に均一な力がかかり, 高い 応力值を示す粒子が存在しないことが判る。

炉内での粒子の圧潰を防止するためには, 最大応力の小 さい（b）の方が有利である。また，フェロコークスは乾留 により強度が上がるため, 炉下部の応力がかかる部位で は, 強度が十分に上昇した製品が通過するように調整を行 うことが必要となる。

\section{$3 \cdot 2$ 粒子の排出方法の滞留時間分布への影響}

乾留工程において高温場での乾留物保持時間は製品の性 状に大きく影響するため, 竪型乾留炉の縦方向中央部分を 乾留温度域として, DEMにより粒子の滞留時間を算出し た。Fig.7に濃灰色で示すように，炉下部より $9 \mathrm{~m}$ の位置に $0.2 \mathrm{~m}$ 厚のトレーサー層を配置し，炉下部より $4 \mathrm{~m}$ の位置を トレーサー粒子が通過する時間あるいは割合を算出した。

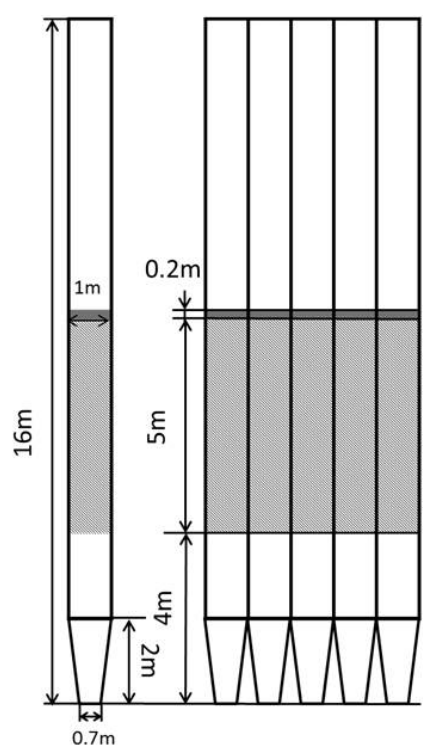

Fig. 7. Initial position of tracer and region for residence time calculation.

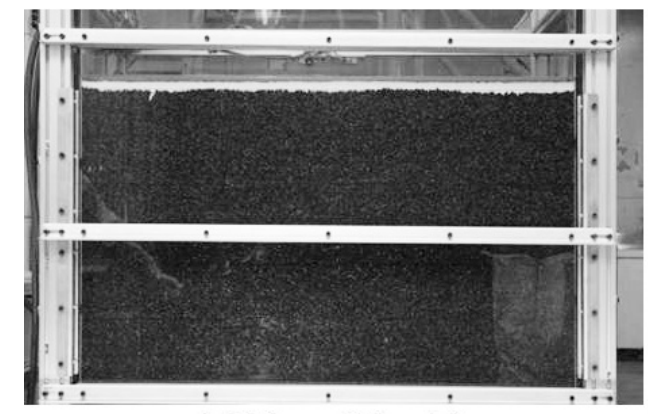

Initial condition (a)

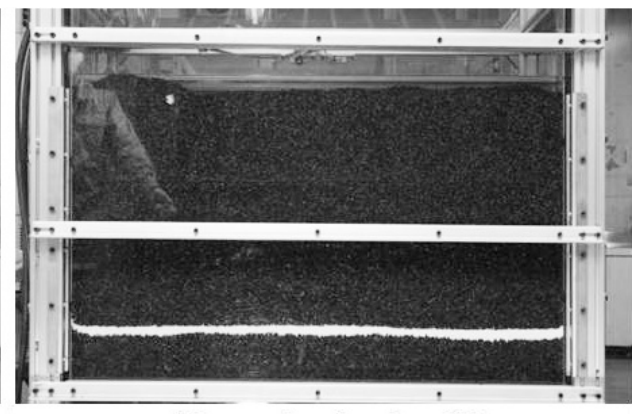

After carbonization (b)

Fig. 5. Descent behavior observation by the cold model. 
炉下部の排出は掻き出し装置による間欠排出を再現するた めに, 炉下部の $0.6 \mathrm{~m}$ (a), $0.3 \mathrm{~m}$ (b) 厚の粒子層を同時に消 去し，粒子層を降下した。このような間欠排出では Fig.2の 模式図に示すように，掻き出しにより粒子が排出され，そ の直後に粒子が重力により自由落下し, 全体の粒子が落下 後に動きが止まり, 充填層が安定する。このサイクルを繰 り返すことで充填層全体が降下する。シミュレーション上 では 1.0 秒ごとに排出を行った。実炉での装入物全体の平 均降下速度が $2.5[\mathrm{~m} / \mathrm{h}]$ になる様に (a)，(b) の排出間隔 1.0 $\mathrm{s}$ を，それぞれ実炉での $6.2 \mathrm{~min}, 2.85 \mathrm{~min}$ に換算して滞留時 間分布を求めた。この時，最初に排出されるトレーサーの 滞留時間は2時間となる。

上記の条件で炉中間部を縦方向に $5 \mathrm{~m}$ トレーサーが移動 した割合を, Fig.8に示す。縦軸は各排出の後, 充填層が安 定した時に高さ $4 \mathrm{~m}$ の位置を通過したトレーサーの割合を 示す。横軸は最初に通過したトレーサーを基準 $(0 \mathrm{~min})$ と した経過時間を示す。プロットは各排出時での通過割合を 示している。通過割合が増加するに従い，一回当たりの排 出での通過割合の増加は低減する。トレーサーの $99 \%$ が通 過するには最初のトレーサーの通過から, 40 min ほどの時 間を要する。一回の排出当たりの粒子の排出量が多く，排

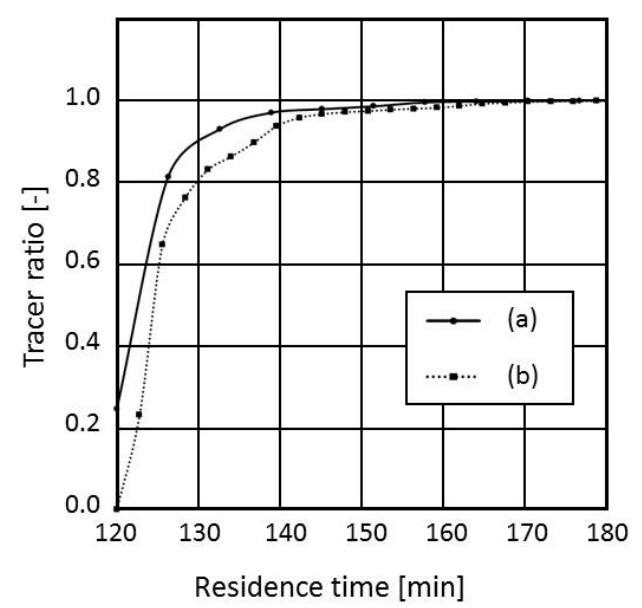

Fig. 8. Effect of discharging region and frequency on relationship between residence time and passed tracer ratio. 出回数の少ない（a）の条件では最初のトレーサー検出位 置に達してから 2 回の排出で8割程度, 3 回の排出で9割以 上のトレーサーが高温部を通過することが判る。(b)では 通過割合が 8 割, 9割に達するまでの排出回数はそれぞれ 4 回, 7 回である。一回当たりの排出間隔を考虑すると, 卜 レーサーが 8 割通過するまでにかかる時間の差は約 10 分, 9割通過するまでにかかる時間の差は約15分である。これ らの時間差は基準となる2時間に対してそれぞれ約 8.3 , $12.5 \%$ の差となる。

トレーサーの上下方向の分布は壁の摩擦によるため, Fig.4のように壁面近傍の粒子が遅れ上側に，中央付近の 粒子は下側に分布する。特に両端の粒子の遅れが大きいた め, 両端のユニットからの排出速度を高め粒子の降下を調 整することを試みた。

Fig.9に示すように，(a) 均一に炉下部 $30 \mathrm{~cm} ，(\mathrm{~b})$ 両端 の炉下部 $40 \mathrm{~cm}$ ，中央の炉下部 $30 \mathrm{~cm} ，(\mathrm{c}$ ) 両端の炉下部 50 $\mathrm{cm}$ ，中央の炉下部 $30 \mathrm{~cm}$ 回あたりの粒子排出の領域と した。Fig.10は各排出条件での計算開始から実炉換算で 100 minが経過した時点の粒子の分布を示す。両端部の排 出量を増やした (b)，(c) では，テーパー部でのトレーサー (黄色)の分布に大きな差がある。これに対して炉体中部の

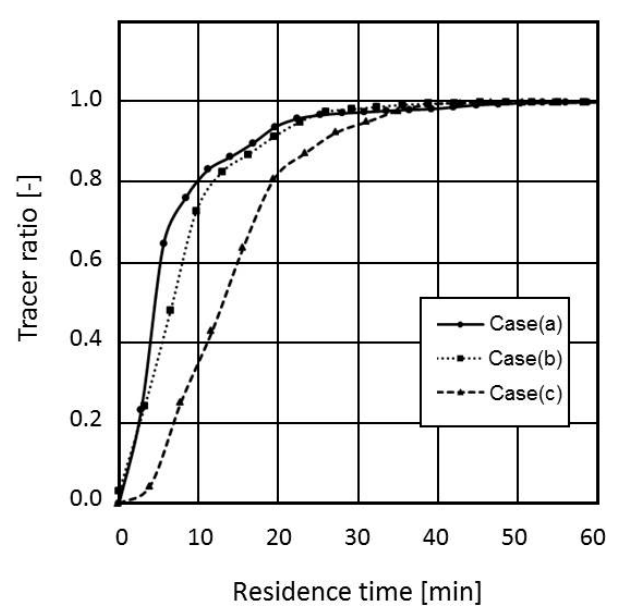

Fig. 11. Effect of discharging condition on relationship between residence time and passed tracer ratio.

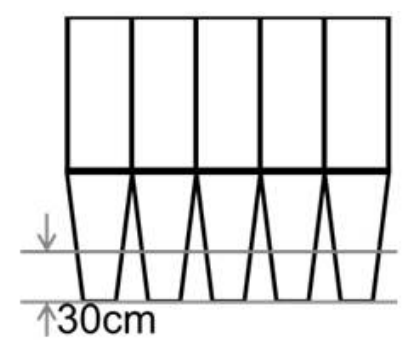

Case(a)

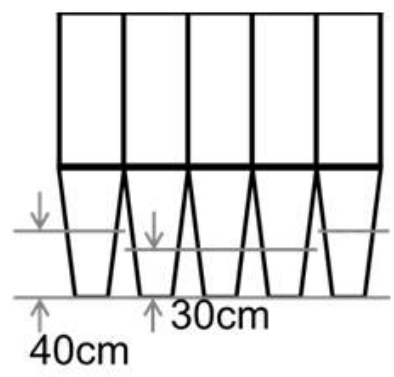

Case(b)

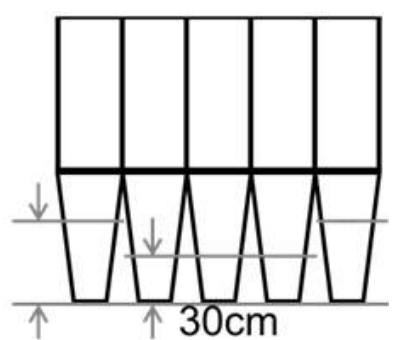

$50 \mathrm{~cm}$

Fig. 9. Variation of discharging region for controlling residence time of particle. 
トレーサー (赤色) の分布はテーパー部に比べ, 変動が小 さいことが確認できる。これらより，狙い通り排出方法に より壁面部での遅れを緩和することが可能であることが分 かった。本研究では, 炉底より $4 \mathrm{~m} ら 9 \mathrm{~m}$ までの区間を 乾留温度域として設定したため，炉下方テーパー部でのト レーサー分布の変動は乾留時間に影響を与えない。

Fig.11に炉中間部を縦方向に $5 \mathrm{~m}$ トレーサーが移動した 割合と時間の関係を示す。Fig.9 (a) の条件では, 初期の粒 子排出が均一であるが, 通過割合が 0.96 以上で両端の工 ニットの角の粒子の停滞が顕著に表れる。(b) では0.96以 上での粒子の通過割合の上昇が (a) より高く壁の分布拡 大への影響を緩和していることが判る。(c)では中心部ユ ニットから端のユニット領域への粒子の流れ込みが顕著に なり全体にトレーサーの分布が大きくなることが判る。し かし, 最初のトレーサーが $5 \mathrm{~m}$ 降下してから 9 割 9 分が通過 するまでの時間は条件 (a) よりも短く, 極端に長時間滞留 する粒子割合が低下することが判る。

粒子の帯留時間を均一に制御するためには (b) に示すよ うに並列したユニットの両端の降下速度を中心部より若干 高め, 壁の摩擦による降下分布を減少することが有効であ ると考えられる。

\section{$3 \cdot 3$ 炉内支柱の粒子降下挙動への影響}

\section{$3 \cdot 3 \cdot 1$ 支柱径の粒子への影響}

矩形に炉体を拡張する際に, 短辺方向への炉体の変形 を防ぐために, 炉内に支柱を設置した際の粒子降下挙動 への影響を計算した。支柱の太さは直径 $20 \mathrm{~cm}$ と $40 \mathrm{~cm}$ の 円柱とし, 2 ・1 項で述べたように, 炉底から $8 \mathrm{~m}$ の位置に 2本設置した。ここではトレーサー粒子を炉下部から $3 \mathrm{~m}$, $6 \mathrm{~m}, 9 \mathrm{~m}, 12 \mathrm{~m}$ の位置に設置し, 粒子の降下による分布の 変化を計算した。シミュレーション上では炉底から $40 \mathrm{~cm}$ の位置を粒子の排出範囲として $1.0 \mathrm{~s}$ 毎に排出を行った。 Fig. 12 に降下開始直後, $4.0 \mathrm{~s}$ 経過後, $8.0 \mathrm{~s}$ 経過後を示す。卜 レーサー粒子が支柱の周辺で動きが変化し, 分布に乱れが 生じることが判る。 $8.0 \mathrm{~s}$ 経過後の分布から, $20 \mathrm{~cm}$ の支柱 では支柱の位置のトレーサー粒子が遅れ, $40 \mathrm{~cm}$ の支柱で は支柱位置のトレーサー粒子が先行することが確認でき る。
Fig.13にトレーサー粒子が支柱の上部に達した時と，下 部に達した時の速度べクトルを示す。支柱上部において 20 $\mathrm{cm}$ では支柱直上の粒子速度が低下し, 支柱の間の粒子の 速度が上昇しているが，40 cmでは支柱上部の粒子が相対 的に速い速度で支柱の間に流れ込むことが判る。また支柱 下部に抏いても, 速い速度で支柱の下に粒子が流れ込むこ とが判る。この挙動から, $40 \mathrm{~cm}$ ではもともと支柱の間に 位置したトレーサー粒子が, 支柱の下側に回り込み降下が 先行する。また, 支柱の上部に位置した粒子は支柱の間を 遅れて降下したことが判る。

Fig.14に支柱周辺に打ける粒子降下時の応力分布を示 す。色は応力の強度を示す。両条件も支柱の直上の粒子に 大きな応力がかかっていることが判る。40 cmでは支柱間 への流れ込の影響で, 支柱の間での応力が大きくなってい ることが判る。また, 支柱直下に応力が低下する領域が確 認できる。粒子にかかる応力の観点から, 径の小さい支柱 が有利であることが明確に示された。

$3 \cdot 3 \cdot 2$ 支柱径の調整による粒子降下の均一化

支柱の径により支柱の位置でのトレーサーの遅れや先行 が確認された。ある径の支柱を用いれば, 支柱により粒子 の遅れと先行が相殺される可能性がある。そこで, 支柱の 直径を $1 \mathrm{~cm}$ 単位で変化させて粒子の降下挙動を算出した。 Fig. 15 に支柱直径 $35 \mathrm{~cm}, 36 \mathrm{~cm}, 37 \mathrm{~cm}$ における, 支柱位置 を通過後約 $4 \mathrm{~m}$ 降下したトレーサー粒子の分布変化を示 す。通過後のトレーサー粒子の分布を $35 \mathrm{~cm}$ では支柱の影 響で支柱位置の粒子の遅れが確認できる。また, $37 \mathrm{~cm}$ で は40 cmでの条件に比べると分布が小さいが, 支柱位置の 粒子の先行が確認できる。 $36 \mathrm{~cm}$ では粒子の遅れ, 先行の 両方が見られるが, 他の条件に比べ上下方向の分布が小さ くなることが判る。支柱周り粒子の遅れと先行の境界は 36 $\mathrm{cm}$ 付近にあると考えられる。また, このような支柱を選択 することで, 粒子の滞在時間の分布を縮小できる可能性が ある。しかし, 支柱の影響による粒子流れの乱れは上下方 向の分布を拡大する。この乱れを無くすことは困難である ため, 粒子の乾留時間の均一化には支柱を用いないことが 望ましい。

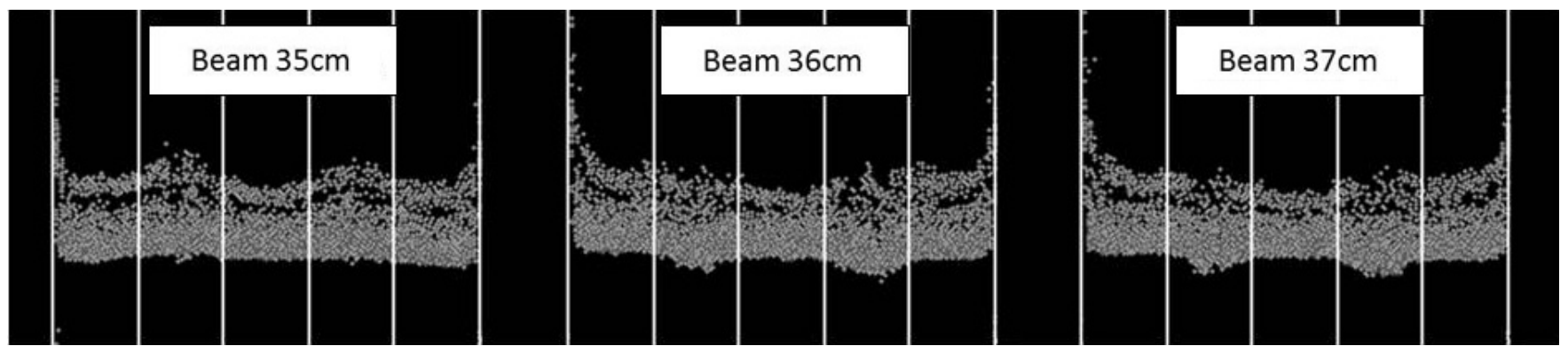

Fig. 15. Effect of beam diameter on tracer particle distribution. 


\section{4. 結言}

パイロットプラントスケールのフェロコークス竪型乾留 炉を並列に配置し，矩形竪型乾留炉にスケールアップする ことを想定し，炉内での粒子の挙動をDEMにより解析を 行った。炉下部の形状および排出方法と粒子の滞留時間お よび粒子にかかる応力の関係を導出した。また，実炉体の スケールアップ時の強度保持を考慮し, 炉内の補強材の粒 子運動への影響も考察した。以上より以下の知見を得た。

1）炉体を並列化することで，2面の炉壁により降下が遅 れる角の影響が小さくなり, 全体の降下速度が均一化す る。

2）ユニット毎に排出口を設置する場合，粒子の滞留時間 への影響は小さいが，炉下部の縮流により粒子へ応力が集 中する。

3）並列化した端のユニットの粒子降下が遅くなるため, 端の排出速度を中央部に比べ上昇することで, 粒子の滞留 時間の均一化が図れる。

4）炉内に支柱を設置した場合, 支柱の直径により支柱位 置の粒子の降下が促進あるいは遅滞する。その境界の支柱 径を用いることで上下方向の粒子の分布拡大を緩和できる 可能性がある。

\section{謝辞}

本研究はNEDO「資源対応力強化のための革新的製銑プ ロセス要素技術開発事業」の一環として行われたものであ ることを記すとともに, 実験結果の提供を頂きましたJFE スチール研究所の関係者の方々に謝意を表します。

\section{文献}

1 ) S.Nomura, H.Ayukawa, H.Kitaguchi, T.Tahara, S.Matsuzaki, M.Naito, S.Koizumi, Y.Ogata, T.Nakamura and T.Abe: ISIJ Int., 45(2005), 316

2 ) S.Nomura, H.Kitaguchi, K.Yamaguchi and M.Naito: Tetsu-toHagané, 92(2006), 481.

3 ) T.Yamamoto, T.Sato, H.Fujimoto, T.Anyashiki, M.Sato and K.Takeda: Tetsu-to-Hagané, 96(2010), 683.

4 ) T.Yamamoto, H.Fujimoto, T.Anyashiki, K.Fukada, M.Sato, K.Takeda and T.Ariyama: Tetsu-to-Hagané, 97(2011), 501.

5 ) T.Kon, K.Kojima, S.Natsui, S.Ueda, R.Inoue and T.Ariyama: Tetsuto-Hagané, 98(2012), 459.

6 ) P.A.Cundall and O.D.L.Strack: Geotechnique, 29(1979), 47.

7 ) M.Ichida and H.Biausser: Tetsu-to-Hagané, 69(1983), S61.

8 ) M.Ichida, K.Tamura, Y.Okuno, K.Yamaguchi, M.Nakamura and M.Nakayama: Tetsu-to-Hagané, 78(1992), 58.

9 ) S.Natsui, S.Ueda, M.Oikawa, Z.Fan, J.Kano, R.Inoue and T.Ariyama: ISIJ Int., 49(2009), 1308. 